\title{
Investigation of Cryptosporidium spp. positivity in Formol-Fixed Stool samples by Polymerase Chain Reaction Method
}

\section{Formolle tespit edillmiş dışkı örneklerinde Cryptosporidium spp.'nin Polimeraz Zincir Reaksiyonu Tekniği kullanılarak pozitifliğinin araştırılması}

\author{
U゚lküi Karaman", Zeynep Kolören², Emine Ayaz ${ }^{2}$
}

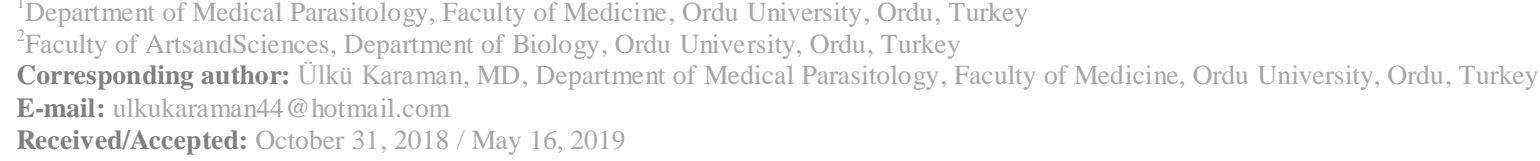

\section{SUMMARY}

Objective: It was aimed to determine Cryptosporidium spp., which is thought to cause digestive system complaints in primary school children, by Modified Acid-Fast (MAF) staining method and Polymerase Chain Reaction (PCR).

Method: One hundred sixty-four stool samples taken from children were examined under light microscopy with MAF. Positive samples were fixed in $10 \%$ formalin and stored at $+4{ }^{\circ} \mathrm{C}$ until analysis. These samples were then purified using the Sucrose Gradient method and, DNA isolation was performed using the modified QIAamp DNA Mini Kit (Qiagen) protocol. In order to increase the sensitivity of the study, the SSU rRNA gene region was amplified by PCR method.

Results: Microscopic examination showed that 89 of the 164 stool samples $(54,26 \%)$ were found to be positive for Cryptosporidium spp.oocysts. Eightynine samples which were found to be positive by microscopic examination and fixed in $\% 10$ formalin were studied by PCR, and $74(45,12 \%)$ of them were positive.

Conclusions: Cryptosporidiosis, which is known to cause severe infections, especially in immunocompromised individuals and children, is transmitted by the fecal-oral route from infected humans and animals, and contaminated water and nutrients. Cryptosporidiosis, which is the result of fecal pollution, causes a great risk for human health even with a low number of oocysts due to the fact that oocysts are resistant to chlorine and they can survive for a long time in the outer environment. It was observed that primary school children living in the area of the study were under risk for cryptosporidiosis. Keywords: Modified Acid-Fast (MAF), Polymerase Chain Reaction (PCR), Cryptosporidium spp.

\author{
ID Ülkü Karaman \\ (D) Zeynep Kolören \\ (iD)Emine Ayaz
}

ORCID IDs of the authors:

Ü.K. 0000-0001-7027-1613

Z.K. 0000-0001-9708-2716

E.A 0000-0003-3982-5459 
Amaç: Çalışmada ilköğretim okulu çocuklarında sindirim sitemi rahatsızlığına neden olabileceği düşünülen Cryptosporidium spp.'ninModifiyeAsit Fast (MAF) vePolimeraz Zincir Reaksiyonu(PZR) ile tespit edilmesi amaçlanmıştır.

Yöntem: Çocuklardan alınan 164 dışkı örneği Modifiye Asit-Fast (MAF) boyama yöntemiyle 1şık mikroskobu altında incelenmiştir. Pozitif bulunan örnekler \%10'luk formolde tespit edilerek inceleme yapilana kadar $+4^{\circ} \mathrm{C}^{\prime}$ de muhafaza edilmiştir. Daha sonra Sükroz Gradient yöntemi kullanılarak saflaştırılan örneklere, modifiye edilmiş QIAamp DNA Mini Kit (Qiagen) protokolü uygulanarak DNA izolasyonu yapılmıştır. Çalışmanın hassasiyetini arttırmak amacıyla SSU rRNA gen bölgesi, PZR yöntemi ile çoğaltılarak örnekler incelenmiştir.

Bulgular: Mikroskobik bakı sonucunda 164 dışkı örneğinin 89'unda $(\% 54,26)$ Cryptosporidium spp.'nin ookistlerine rastlanılmışıtır. Mikroskobik inceleme ile pozitif bulunan ve \%10'luk formolde tespit edilen 89 örnek PZR yöntemi ile çalışılmış ve 74 ’ü $(\% 45,12)$ pozitif olarak belirlenmiştir.

Sonuç: Özellikle bağışıklık sistemi baskılanmış kişilerde ve çocuklarda ağır enfeksiyonlara neden olduğu bilinen Cryptosporidiasis, enfekte insan ve hayvanlarla yakın temasla, kontamine su ve besin yoluyla fekal-oral yolla bulaştı̆ı bilinmektedir. Fekal kirlilik sonucunda meydana gelen bu enfeksiyonun, düşük sayıda ookistle bile meydana gelebilmesi, ookistlerin klora karşı dirençli oluşu ve dış ortamda uzun süre canlı kalabilmesi nedeniyle insan sağlığı için büyük risk oluşturmaktadır. Elde edilen veriler değerlendirildiğinde araştırma alanında yaşayan ilkokul çocuklarının Cryptosporidiasis açısından risk altında olduğu gözlenmiştir.

Anahtar sözcükler: Modifiye Asit Fast (MAF); Polimeraz Zincir Reaksiyonu (PZR); Cryptosporidium spp.

\section{INTRODUCTION}

Cryptosporidium spp. which is an obligate intracellular parasite belongs to the coccidia subgroup of Apicomplexa class. This parasitosis was identified for the first time in gastric crypts of laboratory mice by Ernest Edward Tyzzer in 1907. ${ }^{1}$ Oocysts of the parasite which causes gastroenteritis in many vertebrae and humans are 4-6 $\mu \mathrm{m}$ in size and transmit between organisms with consumption of stool-contaminated water and food..$^{2-4}$

The incidence of Cryptosporidium spp. is high among some occupational groups (persons dealing with animal husbandry, veterinarians, laboratory personnel, day care center personnel), children and elderly people, persons traveling to the endemic areas, those living in environments with poor hygienic conditions, and persons who contact with infected individuals. There have been Cryptosporidium epidemics known to be originated from public swimming pools, food eaten from the same plates, jointly eaten meals, and non-hygienic water resources. ${ }^{6}$ Transitions from animals to humans in rural areas have also been reported. ${ }^{5}$

Cryptosporidiosis symptoms vary depending on the type, immunity, and age of the infected host. ${ }^{7,8}$ The disease causes asymptomatic infection or spontaneously resolved diarrhea in persons with healthy immune system, it may lead to chronic diarrhea with severe progression; pancreas, gallbladder and respiratory tract infections; and mortality. ${ }^{9}$ Lack of clean water and sanitation facilities, crowded home environment, and close contact with reservoir animals are known to increase the prevalence of the parasite. 9 Several studies from Turkey have reported the prevalence between $0 \%-35.5 \%{ }^{8,10,11}$

In this study, we aimed to determine Cryptosporidium spp., which is thought to cause digestive system complaints by Modified AcidFast (MAF) staining method and Polymerase Chain Reaction (PCR) in children attending to Ordu Primary School.

\section{MATERIAL AND METHODS}

Before the beginning of the study, 2018 dated and 174 numbered approval was received from the Ordu University Clinic Research Ethics Committee.

\section{Sample Collection and Purification of the Ocystes with Sucrose Gradient Centrifugation}

Stool samples were collected from the school children, and centrifuged; smears from the sediments were prepared on the slides, dried and examined under a light microscope with X100 magnification using MAF staining method. The positive samples were fixed in $10 \%$ formalin and kept at $+4^{\circ} \mathrm{C}$ until the analysis. Each sample found positive with the microscopic examination was subjected to serial centrifugation in order to remove PCR inhibitors and formol. Stool samples were purified with Sheather's sugar flotation technique described by Karanis and Kimura ${ }^{12}$, and the supernatant portion was removed. The samples were then put into $1 \mathrm{~mL}$ pellet Eppendorf tubes and stored at $-80^{\circ} \mathrm{C}$ until DNA isolation. 
DNA Isolation and Imaging of Cryptosporidium oocysts with PCR Method

DNAs were extracted from all stool samples that were purified with sucrose gradient method, with the QIAamp DNA Mini Kit using the protocol modified by Plutzer et al. ${ }^{13}$

Hot Start Taq DNA Polymerase Kit (Qiagen), 25 mM dNTP mix, 10 pmol CPBD AGF, and CPBDIAGR primers;

(CPBDIAGF: 5'-

\section{AAGCTCGTAGTTGGATTTCTG-3',}

CPBDIAGR: 5'-

TAAGGTGCTGAAGGAGTAAGG-3') and $1 \mu 1$

DNA was used for PCR. Nuclease-free water

(Hyclone, catalog no: SH30538.02) was added so as to provide a total volume of $25 \mu \mathrm{L}$. The reaction mixture prepared was vortexed and left to incubation in PEQlab PCR device at $95^{\circ} \mathrm{C}$ for 15 minutes, at $95^{\circ} \mathrm{C}$ for 30 seconds, at $48.7^{\circ} \mathrm{C}$ for 1 minute, at $72^{\circ} \mathrm{C}$ for 30 seconds ( 45 cycles), and at $72^{\circ} \mathrm{C}$ for 10 minutes. The PRC products obtained were kept at $+4^{\circ} \mathrm{C}$ until the analysis. Positive and negative controls were used for each test. The products were then stained with ethidium bromide and loaded to $1.5 \%$ agar. After running in the gel electrophoresis at $100 \mathrm{~V}$ for 6 a minutes, the bands were displayed under UV (Prizma/Quantum ST4).

\section{RESULTS}

Microscopic examination revealed Cryptosporidium spp. positivity in 89 (54.26\%) of 164 stool samples. Eighteen-nine positive stool samples were fixed in $10 \%$ formalin until PCR analysis. In order to increase the sensitivity of the study, the SSU rRNA gene region was amplified with the PCR method, and $74(45.12 \%)$ of 89 stool samples (Figures 1 and 2). We observed that the data obtained with staining and PCR methods were closely similar.

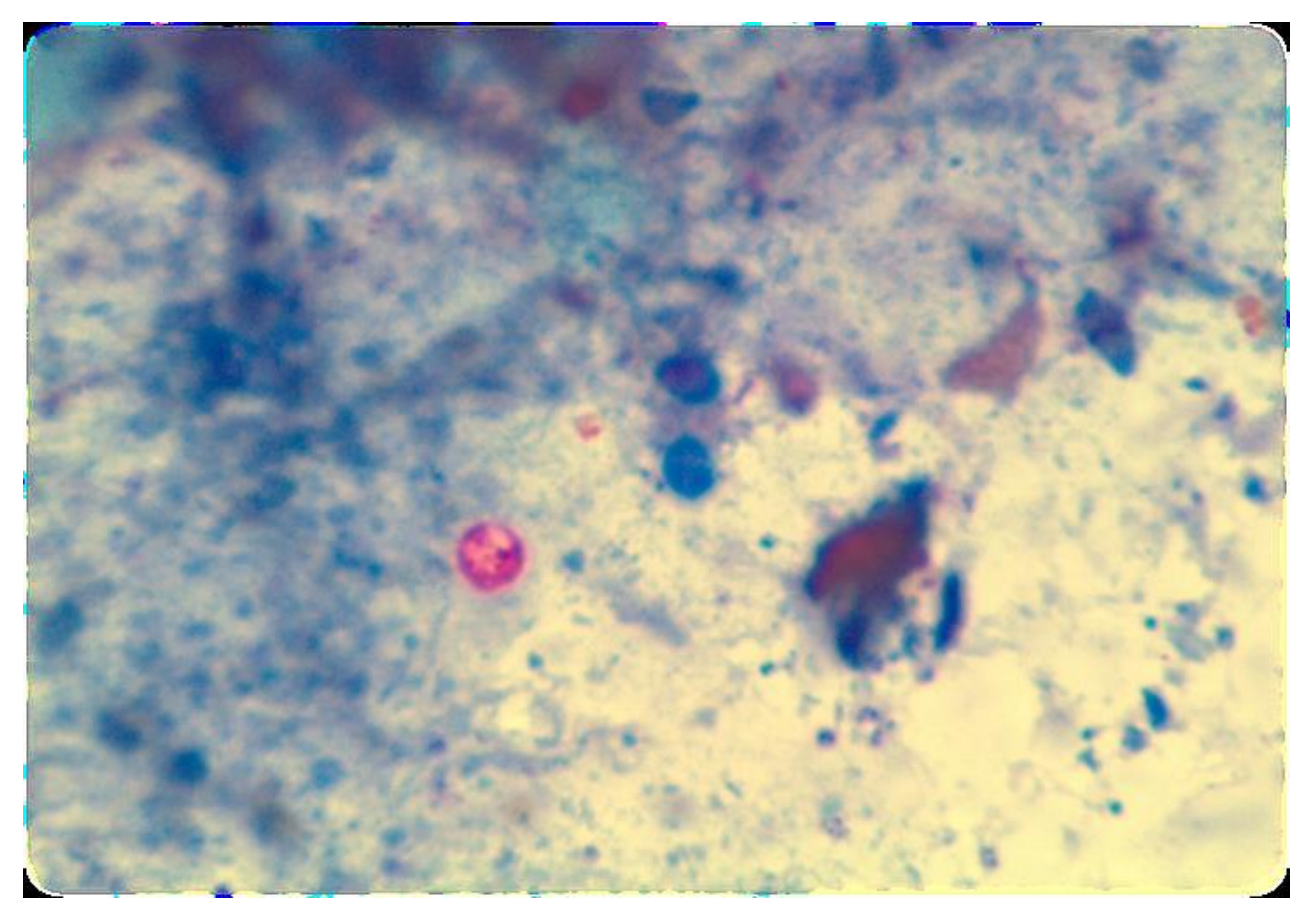

Figure 1: Cryptosporidium spp. detected with the modified acid-fast method. 


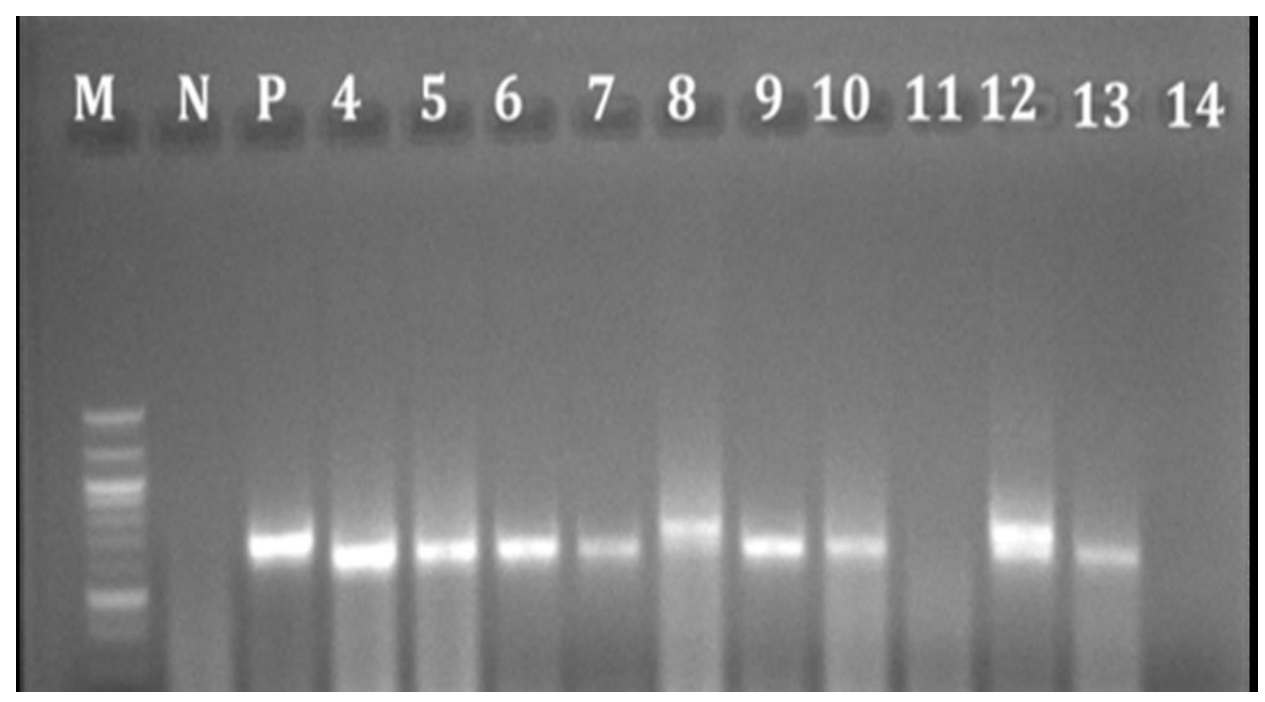

Figure 2: Image of Polymerase Chain Reaction products of stool samples collected from children attending to Ordu Province Kokenli Village primary school, on an agarose gel. M: 100-bp DNA marker; N: distilled water (negative), P: Cryptosporidium IOWA DNA (positive), 4-14 stool samples studied.

\section{DISCUSSION}

According to the literature that we could access, the first study about Cryptosporidiosis infection in Turkey was conducted by Ozcan et al. in Adana province and Cryptosporidium spp. oocytes were detected in $8.2 \%$ of children with diarrhea, and $4.10 \%$ of children without diarrhea. In the later years, studies for this infection have been speeded up, because of the increase in the number of immunocompromised cases and the introduction of new laboratory diagnostic methods. ${ }^{14}$ In a study by Karaman et al. conducted in Malatya, 2281 stool samples were examined with MAF in order to determine the epidemiology of Cryptosporidium spp., and 161 (7.1\%) was found positive. ${ }^{15}$ Again, in a study performed in Van to determine the presence of Cryptosporidiosis, stool samples of 2000 children with 870 being girls and 1130 boys aged between 0 and 15 years who had complaints of diarrhea were studied. In addition, stool samples of randomly selected 100 children were used as the controls. Sample stool collected from the children were studied with MAF and Enzyme-Linked Immunosorbent Assay (ELISA. In conclusion, the presence of Cryptosporidium spp. oocysts were determined in 97 (4.9\%) of 200 children, while staining method found positivity only in $39(1.95 \%)$ children. Both methods could not found parasites in the control group. ${ }^{16}$ In a study by Elgun and Koltas in Adana province between October 2008 and July 2009, Cryptosporidium spp. oocysts were found in 8 (5.19\%) of 154 stool samples with MAF staining method. The authors detected Cryptosporidium spp. the antigen in $37(24 \%)$ of the samples with
ELISA (Microwell ELISA) method. ${ }^{17}$ Similarly, Şahin et al. examined stool samples of 191 villagers living in a village of Buca County who had diarrhea in 1zmir Province with Kinyoun acidfast stain method, and detected Cryptosporidium spp. in 15 (7.9\%) and Cyclospora cayetanensis in $9(4.71 \%)$ of the patients. The authors stated that the possible suspected origin of this outbreak was the contaminated mains water reservoir which provided water to the village. ${ }^{14}$ In the present study, Cryptosporidium spp. was detected in 89 (54.26\%) of 164 stool samples with microscopic examination. Differences among the results of various studies might result from study populations, a region of the study, and the methods used.

Looking at the studies conducted using PCR method; Sungur et al. examined stool samples of 18 children with diarrhea and 27 calves with the diarrheal disease with Nested PCR. The authors identified Cryptosporidium spp. in a total of 9 (20\%) stool samples with 8 (29.70\%) being from stool samples of the calves and one (5.60\%) from a child.18 Again, Sakarya et al. studied a total of 130 stool samples collected from 98 patients who presented to various hospitals in Ankara Province and 32 calves in various cattle breeding farms. ${ }^{19}$ The authors found positive amplification products in $13(10 \%)$ of the samples with $12(37.5 \%)$ being from the calves and one (1.02\%) from the human stools, using Nested PCR method. In a study from Iran, stool samples collected from children $<12$ yo with diarrhea were studied acid-fast staining method in order to determine the presence of Cryptosporidium infection in children, and 
positive samples were subjected to DNA isolation. Next, Thrombospondin-Related Adhesive Protein of Cryptosporidium-2 (TRAP-C2) gene was amplified with Nested PCR using Cryptosporidium spp. specific primers. In conclusion, 12 samples were found to be positive for Cryptosporidium spp. The products obtained were subjected to Restriction Fragment Length Polymorphism (RFLP) technique using (266-366 bp) BstEII and HaeIII enzymes. C. Parvum infection was detected in $10(83.3 \%)$, C. hominis infection in $1(8.3 \%)$ and mixed infection in 1 $(8.3 \%)$ of 12 samples that were found positive with Nested PCR amplification. ${ }^{20}$ Similarly, Ulcay et al. tried to determine which laboratory method should be used to determine intestinal protozoa that may cause gastroenteritis in immunodeficient patients with complaints of diarrhea. ${ }^{21}$ The authors studied 36 immunodeficient patients who had diarrhea for more than 10 days and 44 immunodeficient patients who had no diarrhea: Nativ-Lugol, trichrome, MAF, ELISA, DFA, and PCR techniques for investigation of the stool samples. The authors reported the most common agents responsible for chronic diarrhea in the immunodeficient patients as intestinal protozoa such as Giardia intestinalis and C. Parvum. In addition, DNA was isolated from 162 diarrheal stool samples collected from the patients who presented to the Medical Faculty in Izmir, in order to determine and classify Cryptosporidium spp. Fifteen of 18 samples found positive with Kinyoun acid-fast stain method was found positive also with PCR technique, whereas 6 of 144 samples that could not found positive with staining method were positive with PCR. PCR products of Cryptosporidium spp. oocyst wall protein (COWP) gene region was then cut with RsaI enzyme, and Cryptosporidium meleagridis was found in 1 and C. parvum in 20 samples. $^{22}$ In our study also 89 stool samples found positive with microscopic examination and fixed in 10\% formalin and studied with the PCR method, and $74(45.12 \%)$ samples were found positive.

Another study was performed in order to investigate the efficacy of PCR method in fresh stool samples and samples stored in formaldehyde in the diagnosis of Cryptosporidiosis. In that study, a total of 33 stool samples collected from 22 patients with 23 of the samples being fresh and 10 being fixed in $10 \%$ formaldehyde in the Ege University Medical Faculty Hospital, Department of Parasitology with Nested PCR method. At the end of the study, sensitivity and specificity of PCR were found as $100 \%$ in the fresh stool samples, while sensitivity was found as $50 \%$ in the formaldehyde-fixed samples. ${ }^{23}$ In our study also 89 stool samples found positive with microscopic examination and fixed in $10 \%$ formaline and studied with PCR method, and 74 $(45.12 \%)$ samples were found positive. We found the sensitivity of PCR as $83 \%$. This may be interpreted as that formol-fixed method may increase negativity in PCR outcomes of the parasite.

\section{CONCLUSION}

Cryptosporidiasis, which is known to cause severe infections, especially in immunocompromised individuals and children, is transmitted by fecaloral route from infected humans and animals, and contaminated water and nutrients. Ranching is widespread in the area of this study. Previous studies have reported the incidence of Cryptosporidium spp. as $65.5 \%$ in water found in Ordu and Sinop provinces. In our study, the incidence was found as $54.26 \%$ with $\mathrm{MAF}$ method, and $45.12 \%$ with PCR techniqe. This results suggest that this parasite might be transmited to the patients with contaminated water and animals. We could not find any previous study investigating epidemiology in this parasite in pediatric patients. This study is the first conducted in this area and provided clues about routes of the parasite to infect humans. Accordingly, this study will guide programs about protection against and control of the parasite. In addition, we found that primary school children in the study region might be at risk for Cryptosporidiosis. In the study, children were informed about the transition and protection ways of the parasite, and they were checked up and treated.

\section{REFERENCES}

1. Hashwey R, Smith NH, Cron S, Graviss EA, Chappell, CL, White AC. Cryptosporidiosis in Houston. Texas a report of 95 casesMedicine1997; 76(2): 118-139.

2. Özçelik S, Poyraz Ö, Kalkan K, Malatyalı E, Değerli S. Hayvancılıkla uğraşanlarda ve sığırlardaCryptosporidiumspp. Yaygınlığının ELISA ile araştırılması. Kafkas UnivVet Fak Derg2012;18:A61-A64, DOI:10.9775/kvfd.2011.5981.

3. Clark DP.
insightsintohumancryptosporidiosis. ClinMicrobiolRev 1999; 12:554-563.

4. Griffiths JK. Human cryptosporidiosis: epidemiology, transmission, clinicaldisease, 
treatment, anddiagnosis. AdvParasitol 1998; 40:37-85.

5. Miron D, Kenes J, Dagan R. Calves as a source of an outbreak of cryptosporidiosisamongyoungchildren in an agriculturalclosedcommunity. Pediatr InfectDis J 1991; 10:438-441.

6. Çeliksöz A, Çelik S. Cumhuriyet Üniversitesi Hastanesi'nde gastroenteritli ve malnütrisyonlu hastalarda Cryptosporidiumspp. Araştırması. Türkiye ParazitolDerg 2003; 27: 85-88.

7. Egyed Z, Sreter T, Szell Z, Varga L. Characterization of Cryptosporidiumspp.recentdevelopmentsandfutureneeds. Vet. Parasitol 2003; 111:103-114.

8. Usluca S. İshalli Dışkılarda Microsporidiumspp. veCryptosporidiumspp.' nin Saptanması PCR Yöntemi İle Tür Tayininin Yapılması. Doktora tezi. 2009.

9. Börekçi G, Otağ F, Emekdaş G. Mersin'de bir gecekondu mahallesinde yaşayan ailelerde Cryptosporidiumprevalans1. İnfekDerg 2005;19(1):39-46.

10. Tanyüksel M, Haznedaroğlu T, Gün H. Neoplastik hastalarda Cryptosporidiumspp. Araştırılması. Türkiye ParazitolDerg1995; 19 (1): 56-63.

11. Hazer Y. Afyonkarahisar bölgesindeki risk gruplarında Cryptosporidiumparvum araştırılması. Afyonkarahisar:Afyonkarahisar Kocatepe Üniversitesi Sağllk Bilimleri Enstitüsü. 2007.

12. Karanis P, Kimura A. Evaluation of three flocculation methods for the purification of Cryptosporidium parvum oocysts from water samples. Lett ApplMicrobiol2002; 34:444449.

13. Plutzer J. CryptosporidiumandGiardiaas watercontaminantpathogens in Hungary: $2008 ; 22-25$.

14. Dağ A. Şanlıurfa yöresinde immunsuprese hastalarda Cryptosporidiumspp. sıklığınınkinyoun asit-fast boyama ve elisa yöntemleri ile araştırılması.Uzmanlık Tezi, Harran Üniversitesi, Tıp Fakültesi, Tıbbi Mikrobiyoloji Anabilim Dalı, Şanlıurfa. 2010.

15. Karaman U, Dakdal N, Özer A, Enginyurt Ö, Ertürk Ö. Inc1dence of Cryptosporidiumspp. Inthehumanpopulation of malatya in Turkey, ActaMedMediterr2015, 31: 263
16. Yılmaz, H., Taş, C.Z., Çiçek, M. Investigation of cryptosporidiosisbyenzymelinkedimmunosorbentassayandmicroscopy in childrenwithdiarrhea. SaudiMed J 2008; 29(4): 526-529.

17. Elgün, G.,Koltaş, I.S. Investigation of Cryptosporidiumspp. antigenby ELISA method in stoolspecimensobtainedfrompatientswithdiarr hea. ParasitolRes2011;108(2): 395-7.

18. Sungur T, Kar S, Güven E, Aktaş M, Karaer Z, Vatansever Z. Cryptosporidiumspp'nin dışkıdan Nested PCR ve carbolfuchsin boyama yöntemi ile teşhis edilmesi. Türkiye ParazitolDerg 2008; 32(4): 305-308.

19. Sakarya Y, Kar S, Tanyuksel M. ve ark. Detection of Cryptosporidiumspp. inhumansandcalvesthroughNested PCR andcarbolfuchsinstainingmethods in Ankara, Turkey. Kafkas UnivVet Fak Derg2010; 977 980.

20. Mojarad, N.E.,Keshavarz, A., Taghipour, N., Haghighi, A., Kazemi, B., Athari, A. Genotyping of Cryptosporidiumspp. inclinicalsamples: PCR-RFLP analysis of the TRAP-C2 2 gene. GastroenterolHepatolBedBench2011; 4(1): 29-33.

21. Ülçay A., Görenek L., Coşkun Ö., Araz E., Acar A., Eyigün, C.P. İmmünyetmezlikli hastalarda intestinalprotozoonların tanisı. Türkiye ParazitolDerg2008; 32(4): 328-333.

22. Usluca, A., Aksoy, Ü. Detectionandgenotyping of Cryptosporidiumspp. indiarrheicstoolsby PCR/RFLP analyses. Turk J MedSci2011; 41(6): 1029-1036.

23. Dirim, E.D., Dağc1, H., Turgay, N., Akarca, U.S., Alkan, M.Z. Themoleculardiagnosis of cryptosporidiosis freshandformalinpreservedfecalsamples. Türkiye ParazitolDerg2009; 33(2): 120-4. 